\title{
Screening of some Cost Effective Media for Submerse Cultivation of Macromycetes Mycelium
}

\author{
Georgeta FIDLER $^{* 1,2)}$, Steliana RODINO ${ }^{1,2)}$, Alina BUTU ${ }^{2)}$, Petruta C. CORNEA ${ }^{1)}$ \\ ${ }^{1)}$ University of Agronomic Sciences and Veterinary Medicine, Bucharest, Romania \\ ${ }^{2)}$ National Institute of Research and Development for Biological Sciences, Bucharest, Romania \\ *Corresponding author, e-mail: gina_2801@yahoo.com
}

Bulletin UASVM Animal Science and Biotechnologies 72(1) / 2015

Print ISSN 1843-5262; Electronic ISSN 1843-536X

DOI:10.15835/buasvmcn-asb: 10921

\begin{abstract}
The present paper aimed to study the growth and development of two macromycetes, Flammulina velutipes and Ganoderma applanatum on enriched culture medium as follows: Hwang medium, sorghum deposit and wine yeast. It was found that the influence of culture medium varies depending on the species. The medium containing sorghum lead to increased weight of mycelia biomass for both species, and the yeast wine medium strongly stimulated G. applanatum development, but significantly inhibited the species $F$. velutipes. The results demonstrate that the raw materials with less economic value have a significant potential when used in mushrooms submersed cultivation, because the low costs of the cultivation technology and the use of residues from food industry and industrial by-products lead in this case to obtain profitable technologies for bioproducts.
\end{abstract}

Keywords: byproducts, mushroom, submerse cultivation, macromycetes, mycelium

\section{INTRODUCTION}

Researches on various species of mushrooms proved their usefulness as sources of bioactive compounds. Submersed cultivation of mushrooms on different cultivation substrates from renewable sources is a cost-effective alternative for efficient production of mycelium and metabolites (Philippoussis et al., 2007; Vladimir, 2012). Most of the lignocellulosic wastes (such as wheat, rice, paddy straw, sawdust, cotton waste, straw, corn residues) are available and can be used as cheap substrates for the production of mushrooms and the use of these wastes in cultivation has a high rate of bioconversion (Gaitán et al., 2006).

\section{AIMS AND OBJECTIVES}

The goal of this work was selection of different cultivation substrates from renewable natural sources in order to obtain a mycelium biomass rich in bioactive compounds with antimicrobial and antioxidant properties

\section{MATERIALS AND METHODS}

The mushrooms analyzed were natural isolates of Ganoderma applanatum and commercial strains of Flammulina velutipes. Submersed cultivation was realized on different byproduct as substrates (wine yeast, sorghum deposit resulted from bioethanol production within international project "Biofuels -source of common sustainable development in the cross-border cooperation area"). Both extracts were obtained with distilled water at a ratio of 1: 2 . The mixture was sonicated for 10 minutes at of $45^{\circ} \mathrm{C}$ and an amplitude of $40 \%$, then filtered. For the determination of the dry substance of the two extracts the collected samples were dried at $105^{\circ} \mathrm{C}$ to constant weight. The biuret method was used for the determination of protein. Total carbohydrate content was determined by the method of Scott and Melvin using anthrone reagent and the reducing carbohydrate by spectrophotometric method described by Nelson Somogy. 
Tab. 1. The biochemical determinations

\begin{tabular}{|lccc|} 
& $\begin{array}{c}\text { Dry substance } \\
\%\end{array}$ & $\begin{array}{c}\text { Protein } \\
\text { concentration }(\mathrm{mg} / \\
\mathrm{ml})\end{array}$ & $\begin{array}{c}\text { Total carbohydrates } \\
(\mu \mathrm{m} / \mathrm{ml})\end{array}$ \\
\hline Sorghum deposit extract & 3.65 & $1.056 \pm 0.043$ & $38.343 \pm 2.316$ \\
\hline Wine yeast extract & 3.72 & $9.140 \pm 0.235$ & $66.421 \pm 0.703$ \\
\hline
\end{tabular}

Tab. 2. Weight of the mycelial biomass

\begin{tabular}{|lccc|} 
& medium I (g) & medium II (g) & medium III (g) \\
\hline G. applanatum & 2.3944 & 7.9584 & 27.3523 \\
\hline F. velutipes & 12.1315 & 14.1386 & 4.8439
\end{tabular}

To obtain stock cultures, pieces of fruition corpus were placed in Petri dishes in culture media prepared from malt extract agar $2 \%$ and potato dextrose agar (PDA) and were incubated at $25^{\circ} \mathrm{C}$ for one week.

After growth, $5 \mathrm{~mm}$ mycelium disks cut from growing areas were placed in $500 \mathrm{ml}$ Erlenmeyer flasks each containing $100 \mathrm{ml}$ of liquid medium (I) prepared according to Hwang (II) medium prepared with sorghum deposit extract resulted from bioethanol production (III) medium prepared with wine yeast.

\section{RESULTS AND DISCUSSION}

Considering that wine yeast extract shows superior features than the sorghum deposit one (protein concentration, total carbohydrates), it can be noticed that the nutritional requirements of the two macromycetes are very different (Tab. 1).

Industrial and food industry byproducts are rich sources of sugar and other useful compounds, easily metabolized by mushrooms, leading to large quantities of fungal biomass. As it can be noticed from Table 2, the influence of culture medium varies depending on the species. Thus, $G$ applanatum had the greatest weight in the mycelial biomass culture medium enriched with wine yeast, showing an increase of $24.96 \mathrm{~g}$ higher than the basal medium, while $F$. velutipes grew best on bioethanol sorghum deposit medium (5.56 g versus basal medium).

\section{CONCLUSION}

The results demonstrate that raw materials with less economic value have a significant potential for mushrooms submersed cultivation. The low costs of the cultivation technology can lead to economic advantage at industrial scale. The use of residues from food industry and industrial by-products led case to obtaining profitable technologies. These results are promising, but require further studies to optimize the growth conditions and extraction methods to recover larger amounts of biologically active compounds.

Acknowledgements: This paperwaspublished under the frame of European Social Fund, Human Resources Development Operational Programme 2007-2013, project no. POSDRU/159/1.5/S/13

\section{REFERENCES}

1. Gaitán-Hernández R, Esqueda M, Gutiérrez A, Sánchez A, Beltrán-García M, Mata G (2006). Bioconversion of agrowastes by Lentinula edodes: the high potential of viticulture residues, Appl Microbiol Biotechnol 71: 432439.

2. Philippoussis A, Diamantopoulou P, Israilides C (2007). Productivity of agricultural residues used for the cultivation of the medicinal fungus Lentinula edodes. Int Biodeter Biodegr 59: 216-219.

3. Vladimir E (2012). Submerged Cultivation of Medicinal Mushrooms: Bioprocesses and Products (Review), International Journal of Medicinal Mushrooms, 14(3): 211-239. 